\title{
TELAAH BUKU TEKS PEGANGAN GURU DAN SISWA PADA MATA PELAJARAN BAHASA INDONESIA KELAS VII BERBASIS KURIKULUM 2013
}

\author{
A. Sahrul Asri \\ Universitas Mataram \\ rastayoung84@gmail.com
}

\begin{abstract}
Abstrak
Penelitian ini bertujuan untuk mendeskripsikan kualitas buku teks pegangan guru dan pegangan siswa "Bahasa Indonesia: Wahana Pengetahuan" kelas VII. Salah satu aspek yang memiliki peranan penting dalam pembelajaran di sekolah adalah keberadaan buku teks pelajaran. Dalam hal ini, kualitas buku teks pelajaran yang dijadikan sumber pembelajaran turut menentukan hasil pencapaian tujuan pembelajaran. Pengabaian telaah buku teks berarti mengabaikan mutu pembelajaran juga. Telah banyak diberitakan pada media massa mengenai kasus buku teks yang mencoreng dunia pendidikan khususnya pada jenjang pendidikan dasar. Salah satu kebijakan pemerintah dalam implementasi kurikulum 2013 adalah penggunaan buku pegangan siswa dan dilengkapi oleh buku pegangan guru. Buku tersebut disusun dan didistribusikan oleh pemerintah pusat. Penyusunan buku teks tersebut diduga kurang maksimal akibat terburu-burunya penerapan kurikulum 2013. Pendekatan pada penelitian ini adalah deskriptif kualitatif. Data dalam penelitian ini adalah terkait kualitas, keterbacaan, dan keselarasan buku teks. Data bersumber dari buku teks pegangan guru dan siswa BIWP kelas VII. Teknik pengumpulan data melalui teknik wawancara dan dokumentasi. Sedangkan teknik penganalisisan data menggunakan teknik analisis isi melalui coding, klasifikasi, dan deskripsi. Berdasarkan telaah yang telah dilakukan, hasil penelitian menunjukkan bahwa kualitas buku teks pegangan guru dan buku teks pegangan siswa termasuk pada kategori cukup. Hal ini disebabkan karena terdapat beberapa komponen/subkomponen yang tidak memenuhi standar sebagaimana yang telah ditetapkan oleh BSNP.
\end{abstract}

Kata kunci: telaah, buku teks guru, buku teks siswa, kurikulum 2013

\begin{abstract}
This study aimed to describe the quality of teacher's text book and student's textbook of Bahasa Indonesia: Wahana Pengetahuan Kelas VII. One aspect which has an important part in learning at school is the existence of textbooks. In this case, the quality of textbooks are used as learning resources help determine the achievement of learning objectives. Abandonment study of textbooks is ignore the quality of learning as well. It has been widely reported in the mass media about the case of textbooks, especially at the elementary grade. One of the government's policy in the implementation of the curriculum 2013 is the use of the student textbook and equipped by the teacher textbook. The book was compiled and distributed by the central government. Preparation of textbooks was allegedly less than the maximum due implementation of curriculum 2013. The approach in this research is descriptive qualitative. The data in this study are quality of text books. Data sourced from teacher's textbooks and student's textbook of class VII. Data collection through interviews and documentation techniques. The technique of analyzing data using content analysis techniques through coding, classification, and description. Based on the review that has been conducted, the results showed that the quality of teacher's textbooks and student's textbooks in the category moderate. This is because there are several components/subcomponents that do not meet the standards as set by the National Education Standards.
\end{abstract}

Keywords: study, teacher's textbooks, student's textbook, curriculum 2013

\section{PENDAHULUAN}

Implementasi kurikulum dalam kegiatan pembelajaran sangat dipengaruhi oleh dukungan sumber belajar, sarana dan prasa- rana yang memadai terutama kondisi ruang pembelajaran, perpustakaan, laboratorium dan alat bantu pembelajaran. Salah satu aspek yang memiliki peranan penting dalam 
pembelajaran di sekolah adalah keberadaan buku teks pelajaran. Di samping berfungsi mendukung guru dalam proses pembelajaran, buku teks pelajaran juga merupakan salah satu sumber pengetahuan bagi siswa. Dalam hal ini, kualitas buku teks pelajaran yang dijadikan sumber pembelajaran turut menentukan hasil pencapaian tujuan pembelajaran. Semakin baik kualitas buku teks, maka semakin baik pula pengajaran mata pelajaran yang ditunjang oleh buku teks tersebut. Buku teks Bahasa Indonesia yang bermutu tentunya akan meningkatkan kualitas dan hasil pembelajaran Bahasa Indonesia.

Terkait dengan kualitas buku teks, Badan Standar Nasional Pendidikan (selanjutnya disingkat BSNP) telah mengembangkan beberapa komponen yang dijadikan landasan dalam telaah buku teks. Menurut BSNP, buku teks berkualitas wajib memenuhi empat komponen kelayakan yang meliputi kelayakan isi, kelayakan penyajian, kelayakan kebahasaan, dan kelayakan kegrafikan. Keempat komponen tersebut dijabarkan dalam beberapa indikator yang rinci sehingga guru dapat menerapkannya (Muslich, 2010: 291).

Peranan penting telaah buku teks di atas menunjukkan bahwa upaya telaah buku teks sangat penting untuk dilakukan. Pengabaian telaah buku teks berarti mengabaikan mutu pembelajaran juga. Keberadaan buku teks sebagai sumber belajar justru dapat menjadi sumber masalah dalam pembelajaran tersebut. Kekeliruan atau ketidaktepatan yang ada dalam buku pegangan guru maupun buku pegangan siswa tersebut dapat saja terjadi. Guru sebagai pengendali utama di dalam pembelajaran di kelas perlu mencermati terlebih dahulu terhadap buku siswa maupun buku pegangan guru yang sudah disediakan pemerintah. Buku teks tanpa dilakukan telaah terlebih dahulu pada akhirnya siswa yang menjadi korban. Berbagai kemungkinan dapat saja terjadi. Buku yang tidak sesuai standar kelayakan kualitas dapat menyebab kegagalan dalam menarik minat siswa untuk mempergunakan sehingga berimbas pada motivasi dan prestasi belajar. (Greene dan Petty dalam Tarigan dan Tarigan, 2009: 20).

Sebagaimana kita ketahui, telah banyak diberitakan pada media massa mengenai kasus buku teks yang mencoreng dunia pendidikan khususnya pada jenjang pendidikan dasar. Merebaknya kasus tersebut mengisyaratkan bahwa telaah buku teks sangat penting untuk dilakukan. Setelah melakukan identifikasi awal (prapenelitian) terhadap buku teks Bahasa Indonesia kelas VII berbasis kurikulum 2013, ditemukan beberapa keunggulan dan kelemahannya. Disinyalir masih banyak permasalahan lain yang dapat teridentifikasi dalam penelitian ini.

Selain kasus di atas, bergulirnya wacana penerapan kurikulum baru pada pertengahan tahun 2012 yang diberi nama Kurikulum 2013. Banyak kalangan menduga penerapan kurikulum 2013 terlalu dipaksakan. Hal tersebut berdampak pada persiapan 
pemerintah yang kurang maksimal. Salah satu kebijakan pemerintah dalam implementasi kurikulum 2013 adalah penggunaan buku pegangan siswa dan dilengkapi oleh buku pegangan guru. Buku tersebut disusun dan didistribusikan oleh pemerintah pusat. Penyusunan buku teks tersebut diduga kurang maksimal akibat terburu-burunya penerapan kurikulum 2013. Dengan demikian, patut kiranya dilakukan telaah dengan intensif terhadap buku teks pegangan guru maupun buku pegangan siswa khususnya mata pelajaran Bahasa Indonesia. Hal ini mengingat paradigma pembelajaran pada mata pelajaran Bahasa Indonesia berbeda dengan sebelumnya, sehingga struktur dan muatan buku teks pun berbeda. Walaupun buku teks tersebut disusun oleh pemerintah, namun upaya telaah tersebut perlu dilakukan dengan objektif untuk mendapatkan gambaran objektif buku teks pegangan guru dan siswa.

Berdasarkan pengalaman empiris peneliti sebagai guru Bahasa Indonesia di SMP, tidak dapat dipungkiri buku teks Bahasa Indonesia kelas VII berbasis Kurikulum 2013 menyebabkan kebingungan pada guru dan siswa dalam penggunaannya. Pergeseran paradigma pembelajaran Bahasa Indonesia ke arah pembelajaran berbasis teks membutuhkan adaptasi yang tidak singkat. Hal ini mengingat pada jenjang sebelumnya (SD) siswa belum akrab dengan pembelajaran bahasa berbasis teks. Rasionalitas penelitian ini didukung pula oleh hasil identifikasi permasalahan di lapangan. Guru-guru masih banyak yang kebingungan dengan penggunaan buku teks pegangan guru dan buku teks pegangan siswa. Kondisi demikian menyebabkan guru luput untuk melakukan telaah buku teks.

\section{KONSEP DAN KERANGKA TEORI}

Pembatasan terhadap penafsiran pembaca mengenai beberapa istilah-istilah teknis perlu dijelaskan beberapa konsep dalam penelitian ini agar tidak menyebabkan pemahaman yang bias.

1) Telaah adalah penyelidikan; kajian; pemeriksaan; penelitian (KBI, 2008: 1656). Telaah yang dimaksudkan dalam penelitian ini adalah upaya pengkajian atau penilaian kelayakan buku teks pegangan guru dan siswa berbasis kurikulum 2013.

2) Buku adalah lembar kertas yang berjilid, berisi tulisan atau kosong (KBI, 2008: 229). Buku yang dimaksudkan dalam penelitian ini adalah informasi tercetak di atas kertas yang dijilid dalam satu kesatuan. Buku tersebut merupakan buku pelajaran terdiri atas buku pegangan guru dan buku pegangan siswa yang diterbitkan oleh tim penyusun Kemendikbud.

3) Teks adalah 1) naskah yang berupa katakata asli dari pengarang; 2) kutipan dari kitab suci untuk pangkal ajaran atau alasan; 3) bahan tertulis untuk dasar memberikan pelajaran, berpidato, dan sebagainya (KBI, 2008: 1654). Adapun teks yang dimaksud dalam penelitian ini 
adalah bahasa tertulis termasuk kemungkinan konteks yang menggayutinya.

4) Pegangan adalah pedoman (KBI, 2008:1139). Pegangan dalam pengertian penelitian ini adalah pedoman atau panduan yang diperuntukkan bagi guru dan siswa.

5) Berbasis adalah mempunyai basis; berdasarkan pada (KBI, 2008: 142). Berbasis pada penelitian ini adalah berdasar pada Kurikulum 2013.

6. Kurikulum adalah 1) perangkat mata pelajaran yang diajarkan pada lembaga pendidikan; 2) perangkat mata kuliah mengenai bidang keahlian khusus (KBI, 2008: 845). Adapun kurikulum dalam penelitian ini adalah perangkat operasional.

\section{Teori}

\section{Kurikulum 2013}

Kurikulum merupakan salah satu unsur yang memberikan kontribusi untuk mewujudkan proses berkembangnya kualitas potensi peserta didik tersebut. Kurikulum 2013 adalah sebuah kurikulum yang dikembangkan untuk meningkatkan dan menyeimbangkan kemampuan soft skills dan hard skills yang berupa sikap, keterampilan, dan pengetahuan.

Tujuan dan fungsi Kurikulum 2013 secara spesifik mengacu pada Undang-Undang No. 20 tahun 2003 tentang Sistem Pendidikan Nasional. Dalam undang-undang Sisdiknas ini disebutkan bahwa fungsi kurikulum ialah mengembangkan kema- mpuan dan membentuk watak serta peradaban bangsa yang bermartabat dalam mencerdaskan kehidupan bangsa. Sementara tujuannya, yaitu untuk mengembangkan potensi peserta didik agar menjadi manusia yang beriman dan bertakwa kepada Tuhan Yang Maha Esa, berakhlak mulia, sehat, berilmu, cakap, kreatif, mandiri, dan menjadi warga negara yang demokratis serta bertanggung jawab.

Proses pembelajaran pada kurikulum 2013 untuk semua jenjang dilaksanakan menggunakan pendekatan saintifik. Kemendikbud (2013) memberikan konsepsi tersendiri bahwa pendekatan ilmiah (scientific appoach) dalam pembelajaran di dalamnya mencakup komponen: mengamati, menanya, menalar, mencoba atau mencipta, menyajikan atau mengkomunikasikan.

Pergeseran paradigma pembelajaran abad ke-21 tersebut diakomodasi dalam kurikulum 2013 dalam pembelajaran bahasa Indonesia khususnya. Menurut kurikulum 2013, bahasa tidak hanya sebagai alat komunikasi tetapi sarana mengembangkan kemampuan berpikir. Melalui pendekatan berbasis teks, peserta didik memiliki kesempatan yang banyak untuk membaca, menulis dan mempresentasi isi dan merespon teks yang dibacanya. Pembelajaran berbasis teks dilaksanakan secara bersiklus melalui langkah-langkah membangun konteks, pemodelan teks, penyusunan teks secara bersama-sama, dan penyusunan teks secara mandiri. 
Sementara itu, penilaian pada kurikulum 2013 dilaksanakan melalui prinsip autentic assesment pada ranah sikap, pengetahuan, dan keterampilan (Kusaeri, 2014: 14).

\section{Buku Teks}

Bacon dalam Tarigan dan Tarigan (2009: 12) menyatakan bahwa buku teks pelajaran adalah buku yang dirancang, dipersiapkan, dan disusun oleh para pakar dalam bidangnya serta dilengkapi dengan sarana pengajaran yang sesuai untuk digunakan di dalam kelas. A.J. Loveridge (1970: 9) menyatakan "A textbook is a school-book in which selected material on a certain subject, in a written form which will satisfy a specific learning and teaching situation, is systematically set out for assimilation. ” Buku teks adalah buku sekolah yang memuat bahan yang telah diseleksi mengenai bidang studi tertentu, dalam bentuk tertulis yang memenuhi syarat tertentu dalam kegiatan belajar mengajar, disusun secara sistematis untuk diasimilasikan. Rumusan senada juga disampaikan oleh Muslich (2010: 50-51) buku ajar yang berupa buku teks adalah buku yang berisi uraian bahan tentang mata pelajaran atau bidang studi tertentu, yang disusun secara sistematis dan telah diseleksi berdasarkan tujuan tertentu, orientasi pembelajaran, dan perkembangan siswa, untuk diasimilasikan.

Buku teks pelajaran merupakan salah satu media pembelajaran. Sebagai salah satu media pembelajaran, buku teks pelajaran memiliki beberapa fungsi. Sitepu
(2012: 21) berpendapat bahwa dilihat dari isi dan dan penyajiannya, buku teks pelajaran berfungsi sebagai pedoman manual bagi siswa dalam belajar dan bagi guru dalam membelajarkan untuk mata pelajaran tertentu. Oleh karena itu, buku teks yang terstandar dapat dijadikan sebagai sarana atau sumber belajar untuk meningkatkan dan meratakan mutu pendidikan nasional.

Dari hasil kajian diketahui bahwa buku buku teks yang digunakan di sekolah sekolah di Indonesia terdiri atas empat jenis. Apabila ditinjau berdasarkan klasifikasi buku pendidikan, maka terdiri atas (1) buku teks pelajaran; (2) buku pengajaran; (3 buku pengayaan; dan (4) buku rujukan (Tim Pusat Perbukuan, 2006: 4).

Menelaah buku teks merupakan kajian ilmiah yang dilakukan untuk pengukuran atau penetapan kelayakan kualitas suatu buku teks. Terkait dengan bermutu dan tidaknya sebuah buku teks, perlu dicermati komponen-komponen terkait kriteria kelayakan buku teks. Berbagai kriteria telah banyak dikembangkan oleh para pakar atau secara kelembagaan (BSNP). Landasan teoretis terkait kriteria penilaian dalam penelitian ini adalah kriteria yang telah dikembangkan oleh BSNP yang terdiri atas kelayakan isi, penyajian, kebahasaan, dan kegrafikan.

\section{Buku Teks Pegangan Guru dan Siswa}

Buku pelajaran kelas VII kurikulum 2013 terbagi dalam dua jenis buku yakni 
buku pegangan guru dan buku pegangan siswa. Kedua buku itu bersifat komplementer dan saling melengkapi. Terjadi kekompakan dalam pembelajaran di dalam kelas, mengingat guru dan siswa memiliki pola yang sama dalam mengembangan materi pembelajaran. Menteri Pendidikan dan Kebudayaan menerbitkan sebuah paket yang terdiri atas buku teks pegangan guru dan buku teks siswa untuk digunakan pada kelas VII SMP di seluruh Indonesia yang telah mengimplementasikan kurikulum 2013.

Perubahan kurikulum akan mengubah perangkat dan salah satunya buku pelajaran. Isi dalam buku pelajaran pun dapat disesuaikan dengan pembelajaran oleh guru sama halnya siswa. Dalam buku pelajaran bahasa Indonesia kurikulum 2013 terdapat dua buku berdasar pada pemakaiannya yakni buku siswa dan buku guru. Keduanya memiliki hubungan yang erat, sehingga penggunaanya tidak terlepaskan. Buku siswa membantu siswa dan mengonstruksi pemahaman dalam pembelajaran di kelas.

\section{Metode Penelitian}

Sesuai dengan permasalahan yang telah ditetapkan, maka penelitian ini adalah deskriptif kualitatif. Data dalam penelitian ini adalah terkait kualitas buku teks pegangan guru dan siswa. Sumber data dalam penelitian ini bersumber dari buku teks pegangan guru dan buku pegangan siswa "Bahasa Indonesia: Wahana Pengetahuan" kelas VII. Teknik pengumpulan data dil- akukan dengan teknik wawancara dan dokumentasi. Teknik penganalisisan data adalah proses mengatur urutan data, mengorganisasikannya ke dalam suatu pola, kategori dan satuan uraian dasar (Moleong, 2010: 280). Teknik penganalisisan data yang digunakan dalam penelitian ini adalah teknik analisis isi. Langkah langkah analisis dilaksanakan melalui coding, klasifikasi, dan deskripsi (Missing dalam Bungin, 2011: 231).

\section{PEMBAHASAN}

\section{Kualitas Buku Teks Pegangan Guru}

Berdasarkan BSNP (2014), kualitas buku teks pegangan guru dapat diukur berdasarkan empat komponen. Komponen tersebut adalah komponen tujuan/indikator, proses, penyajian, pengayaan, dan penilaian. Secara umum, kualitas buku teks pegangan guru BIWP kelas VII berada pada kategori cukup.

Kualitas buku teks pegangan guru BIWP kelas VII memiliki kategori baik pada subkomponen kejelasan tahapan pembelajaran dan kejelasan kegiatan siswa. Hal ini termuat pada bab II bagian petunjuk khusus. Bagian ini secara rinci mendeskripsikan strategi pembelajaran Bahasa Indonesia berbasis teks. Strategi pembelajaran ini dilaksanakan secara bersiklus pada setiap jenis teks melalui empat tahapan yaitu, tahap membangun konteks, pemodelan teks, menyusun teks secara bersama-sama, dan menyusun teks secara mandiri. Guru sangat terbantu dengan penjelasan pembelajaran yang 
sangat rinci dalam bagian petunjuk khusus. Dengan demikian, kegiatan siswa dapat berjalan sesuai dengan rincian kegiatan yang telah diuraikan pada bagian petunjuk khusus.

Selain subkomponen di atas, teknik penyajian buku teks berada pada kategori baik. Buku teks menyertakan pendahuluan pada awal setiap bab, konsisten dalam penyajian sistematika bab/subbab, dan berbasis aktivitas. Sementara itu, komponen pengayaan pada buku teks pegangan guru yang termuat pada bab IV dapat memberikan uraian materi tambahan mengenai materi yang dibelajarkan peserta didik.

Selanjutnya, komponen penilaian pada buku teks pegangan guru BIWP kelas VII memuat petunjuk secara jelas kegiatan penilaian yang dilakukan guru selama proses pembelajaran pada setiap Subbab/Bab. Selain itu, buku teks memuat aktivitas yang menggambarkan penilaian kepada siswa yang mencakup penilaian pengetahuan, sikap, dan keterampilan.

Namun, hasil temuan lain terkait kualitas buku teks pegangan guru BIWP kelas VII adalah beberapa komponen/subkomponen penilaian berada pada kategori cukup/ kurang. Pada buku teks pegangan guru BIWP kelas VII tidak ditemukan satu pun deskripsi secara eksplisit tujuan dan indikator pembelajaran untuk pencapaian KD pada setiap awal bab/subbab. Setiap bab/ subbab hanya berisi uraian operasional pembelajaran sebagai petunjuk penggunaan buku teks siswa. Setiap awal bab/subbab hanya dideskripsikan petunjuk khusus pembelajaran. Petunjuk khusus tersebut hanya memuat petunjuk kegiatan-kegiatan pembelajaran berbasis teks tanpa memuat uraian KD pembelajaran Bahasa Indonesia secara eksplisit. dengan tidak dimuatnya tujuan dan indikator pembelajaran, terkesan kegiatan untuk pencapaian indikator dan tujuan pembelajaran tidak terarah dengan baik.

Kekurangan buku teks lainnya adalah tidak diuraikannya penerapan pendekatan saintifik dalam pembelajaran Bahasa Indonesia dengan detail seperti penerapan pembelajaran berbasis teks. Berdasarkan uraian dari Kemendikbud (2013: 14) pendekatan saintifik dalam pembelajaran meliputi mengamati (observing), menanya (questioning), mengumpulkan informasi, mengasosiasikan, mengkomunikasikan untuk semua mata pelajaran. Langkah pembelajaran saintifik tersebut adalah pendekatan utama untuk semua mata pelajaran, termasuk Bahasa Indonesia. Namun, terkesan bahwa pembelajaran berbasis teks merupakan pendekatan utama dalam pembelajaran Bahasa Indonesia.

Selanjutnya, sejatinya buku teks pegangan guru dapat merangsang guru untuk mengembangkan diri dalam memecahkan masalah-masalah dalam pembelajaran Bahasa Indonesia. Buku teks seharusnya memuat alternatif contoh-contoh penyelesaian permasalahan yang dapat dilakukan guru untuk memecahkan masalah-masalah yang ada di buku siswa. Namun, terkesan buku teks pegangan guru merupakan buku 
"kunci jawaban" untuk latihan-latihan soal yang ada pada buku pegangan siswa. Hal ini pada akhirnya membunuh kreativitas guru untuk mengembangkan kemampuan kognisi dan psikomotorik dalam memecahkan masalah.

Sementara itu, pada komponen penilaian buku teks pegangan guru BIWP kelas VII berbasis aktivitas lebih menonjolkan penilaian pengetahuan dan penilaian keterampilan saja. Sedangkan, penilaian sikap tidak diuraiakan dengan detail mengenai bentuk penilaian, instrumen penilaian, dan rubrik penilaiannya.

\section{Kualitas Buku Teks Pegangan Siswa}

Berdasarkan BSNP (2014), kualitas buku teks pegangan siswa dapat diukur berdasarkan empat komponen. Komponen tersebut adalah komponen isi, penyajian, kebahasaan, dan kegrafikan. Secara umum, kualitas buku teks pegangan siswa BIWP kelas VII berada pada kategori cukup.

Hasil temuan menunjukkan kualitas buku teks pegangan guru BIWP kelas VII memiliki kategori baik pada komponen isi adalah mencantumkan sumber rujukan berbasis TIK melalui situs. Peserta didik atau satuan pendidikan yang memiliki fasilitas internet dapat mengunjungi laman situs tersebut. Diharapkan penulisan alamat situs tersebut dapat merangsang keingintahuan peserta didik mengenai objek tersebut melalui eksplorasi situs sejenis baik secara online atau offline.
Pemahaman materi merupakan tahap lanjutan setelah membaca dan menyimak teks (percakapan, laporan utuh, gambar, ilustrasi). Pemahaman teks yang dimaksudkan berupa perintah atau latihan yang mengarahkan peserta didik untuk memahami bentuk, struktur, dan isi/pesan teks. Fakta kebahasaan/kesastraan merupakan uraian materi yang disajikan di dalam teks dalam hal muatan fakta kebahasaan atau kesastraan dirancang sesuai dengan tuntutan untuk pencapaian KI dan KD berdasarkan ruang lingkup empat kompetensi inti (kompetensi inti sikap spiritual, kompetensi inti sikap sosial, kompetensi inti pengetahuan, kompetensi inti keterampilan).

Pada komponen penyajian, sistematika penyajian buku teks disampaikan secara jelas, fokus, dan taat asas dalam setiap bab, yakni ada bagian pendahuluan (berisi tujuan penulisan buku teks pelajaran, tujuan pembelajaran, sistematika buku, cara belajar yang harus diikuti, serta hal-hal lain yang dianggap penting bagi peserta didik), bagian isi (pembentukan konteks, uraian, wacana, teks, gambar, ilustrasi, perlatihan, dan pendukung lain), serta bagian penutup (rangkuman, ringkasan), serta relevan dengan pokok bahasan sehingga mampu membangkitkan rasa senang dan pemenuhan keingintahuan peserta didik dalam belajar.

Selanjutnya, materi, perlatihan, atau contoh yang disajikan melalui wacana, teks, gambar, dan ilustrasi pada buku teks pegangan siswa BIWP kelas VII dapat membuka 
wawasan peserta didik untuk mengenal dan menghargai perbedaan budaya, pendapat, penampilan, dan peninggalan leluhur budaya bangsa, mengenal persebaran keanekaragaman alam dan makhluk hidup, serta keunikan setiap daerah. Pada beberapa teks menyajikan kekayaan budaya dan folklor dari beberapa suku yang ada di Indonesia.

Selain itu, buku teks pegangan siswa BIWP kelas VII memuat materi melalui wacana, teks, gambar, dan ilustrasi menempatkan peserta didik sebagai subjek pembelajaran sehingga uraian dalam buku mampu membentuk kemandirian belajar peserta didik, mengakomodasi belajar aktif berorientasi pendekatan saintifik (mengamati, menanya, mengumpulkan informasi/eksprimen, mengasosiasikan/ mengolah informasi, mengomunikasikan). Penyajian materi bersifat interaktif dan partisipatif yang memotivasi peserta didik terlibat secara mental dan emosional dalam pencapaian $\mathrm{KI}$ dan $\mathrm{KD}$ sehingga peserta didik termotivasi untuk belajar secara komprehensif tentang berbagai persoalan kebahasaan dan kesastraan.

Buku teks pegangan siswa BIWP kelas VII pada bagian membangun konteks memuat materi melalui wacana, teks, gambar, dan ilustrasi yang dapat mengembangkan motivasi belajar siswa dan merangsang peserta didik untuk berpikir kreatif tentang apa, mengapa, dan bagaimana mempelajari materi pelajaran dengan rasa senang dalam mengembangkan kompetensi sikap spiritual dan sikap sosial.
Lebih lanjut, komponen kegrafikan buku teks pegangan siswa termasuk pada kategori baik. Seluruh subkomponen pada komponen kegrafikan buku teks telah memenuhi kriteria kelayakan dari segi ukuran, desain kulit buku, dan desain isi buku. Ukuran buku teks pegangan siswa BIWP kelas VII sesuai dengan standar ISO yaitu ukuran B5 (176 mm x $250 \mathrm{~mm})$. Toleransi perbedaan ukuran antara 0 s.d. $20 \mathrm{~mm}$. Desain kulit buku dirancang dengan baik, tipografi yang proporsional, ilustrasi yang menarik dan sesuai dengan isi buku. Sedangkan, desain isi buku dirancang dengan layout standar yang intens, judul pada bab/subbab ditulis dengan warna kontras, hirarki penomoran yang konsisten, dan tipografi isi buku yang proporsional.

Namun, hasil temuan lain terkait kualitas buku teks pegangan siswa BIWP kelas VII adalah beberapa komponen/subkomponen isi termasuk kategori cukup/kurang. Hasil temuan pada komponen isi menunjukkan terdapat beberapa uraian materi pada buku teks pegangan guru BIWP kelas VII tidak sesuai dengan KI dan KD pada silabus. Uraian materi pada buku teks belum menunjukkan kriteria kelengkapan dan kedalamannya. Lingkup materi untuk semua jenis teks pada silabus mencakup pengenalan struktur teks, perbedaan teks dengan teks lain dilihat dari struktur isi, perbedaan teks dilihat dari fitur bahasanya, klasifikasi teks, kelebihan teks dari aspek isi dan bahasanya, kekurangan teks teks dari aspek isi dan bahasanya, pemahaman kata, istilah dalam 
teks, pemahaman isi teks, langkah menyusun teks, aspek penelahaan teks, merevisi isi dan bahasa teks, langkah menyusun ringkasan.

Selain aspek kelengkapan materi, aspek kedalaman materi belum terpenuhi pada buku teks pegangan siswa BIWP kelas VII. Materi yang diuraiakan pada buku teks hanya ulasan umum. Uraian teoretis materi sangat terbatas untuk dijadikan sebagai acuan dalam memahami konsep pada setiap teks. Implikasi kedalaman materi pada berbagai jenis teks menerapkan konsep kegiatan pembelajaran melalui pembangunan konteks, pemodelan, latihan/tugas/kegiatan kelompok maupun mandiri.

Selain itu, uraian materi tentang ciri kebahasaan setiap jenis teks tidak memiliki uraian yang secara khusus menunjukkan ciri kebahasaan jenis teks tersebut. Uraian materi tentang fitur kebahasaan terkesan sekadar disisipkan pada setiap jenis teks. Namun fitur kebahasaan tersebut sebenarnya tidak menunjukkan ciri kebahasaan yang khusus digunakan pada setipa jenis teks tersebut. Bahkan, persebaran uraian materi tentang kebahasaan tidak terpetakan dengan baik. Peta konsep materi kebahasaan tidak sesuai dengan tingkat perkembangan kognisi peserta didik pada jenjang SMP.

Selanjutnya, uraian teoretis mengenai sastra pada buku teks pegangan siswa memiliki porsi yang tidak berimbang dengan materi kebahasaan. Uraian materi mengenai sastra hanya dimuat pada bab tersendri adalah teks cerita pendek. Sedangkan, genre sastra lain seperti puisi, novel, dan drama tidak memiliki ruang pembahasan pada bab tersendiri. Kondisi ini menjadi isu klasik yang tidak memiliki masa depan yang jelas dalam dalam pembelajaran Bahasa Indonesia.

Selanjutnya, uraian substansi antarbab tidak proporsional dengan KI dan KD. Secara keseluruhan, beberapa perlatihan, contoh, ilustrasi, atau gambar secara tidak seimbang dengan kebutuhan tiap-tiap pokok bahasan. Terdapat dua bab yang membahas tentang teks eksposisi. Komposisi tersebut tidak berimbang dibandingkan materi teks lain yang masing-masing dibahas dalam satu bab. Jika komponen kompleksitas teks dijadikan bahan pertimbangan untuk menentukan komposisi halaman, teks yang lain juga seharusnya memiliki porsi yang sama. Hal ini mengingat tradisi literasi peserta didik sangat rendah. Pada jenjang sebelumnya, peserta didik tidak memiliki kompetensi yang mumpuni untuk berhadapan dengan pembelajaran berbasis teks. Disinyalir kondisi ini disebabkan karena jumlah teks yang akan dipelajari selama dua semester adalah lima buah jenis teks. Tentu saja jumlah ganjil tersebut menyulitkan penulis untuk membagi pembahasan ke dalam dua semester. Hal ini menyebabkan sebuah teks terpaksa dibahas masing-masing dalam satu bab pada semester ganjil dan genap.

Hasil temuan terkait komponen penyajian adalah mengenai kelengkapan penyajian buku teks yang tidak sesuai dengan standar 
yang telah ditetapkan oleh BSNP. Hasil temuan menunjukkan beberapa bagian sajian tidak termuat pada buku teks seperti pada bagian tujuan penulisan buku teks pelajaran tidak terurai pada halaman tersendiri. Tujuan penulisan buku hanya termuat pada bagian kata pengantar dengan porsi yang padat. Selanjutnya, bagian tujuan pembelajaran juga tidak terurai secara eksplisit dan memiliki space tersendiri pada bagian pendahuluan buku teks pada setiap bab buku teks.

Selanjutnya, sistematika buku juga tidak secara eksplisit diuraiakan. Sistematika buku hanya dapat diidentifikasi secara tidak langsung pada daftar isi di bagian pendahuluan buku teks. Sistematika buku teks tidak dideskripsikan secara khusus pada halaman tersendiri. Selanjutnya, hal-hal lain yang dianggap penting bagi peserta didik juga tidak terakomodasi pada halaman tersendiri. Bagian lain yang teridentifikasi adalah bagian rujukan pada ilustrasi dan tabel tidak memiliki judul dan rujukan yang jelas. Ilustrasi dan tabel hanya disajikan secara eksplisit tanpa membubuhkan nama dan rujukan tabel atau ilustrasi dengan jelas. Pada bagian lain juga, teridentifikasi pada bagian evaluasi tidak termuat pada akhir bab. Secara keseluruhan buku teks berisi latihan dan tugas. Namun, disayangkan pada bagian akhir bab tidak memuat evaluasi secara keseluruhan kegiatan dan tugas yang sudah dilalui pada bagian akhir bab.
Lebih lanjut, penyajian uraian materi mengenai pengenalan, pencermatan, analisis, ringkasan, dan revisi teks tidak diuraikan pada setiap bab atau jenis teks. Penyajian uraian materi tersebut dimuat pada bab tersendiri yaitu bab VII dan bab VIII. Untuk menuntaskan pemahaman peserta didik mengenai setiap jenis teks, sebaiknya tidak dibahas pada bab yang terpisah. Hal ini menyebabkan pemahaman peserta didik tidak terserap secara holistik. Hal ini menyebabkan penggunaan buku teks tidak efektif karena harus "bolak-balik" membuka halaman yang berbeda untuk mempelajari satu jenis teks.

Pada komponen kebahasaan, hasil temuan menunjukkan bahwa penggunaan bahasa yang tidak sesuai dengan tingkat perkembangan intelektual siswa. Istilahistilah yang digunakan banyak yang harus diterjemahkan dengan menggunakan kamus bahasa. Terdapat beberapa istilah atau frasa yang membingungkan peserta didik untuk jenjang SMP

\section{SIMPULAN}

Berdasarkan telaah yang telah dilakukan pada bab sebelumnya, maka dapat diuraian beberapa simpulan bahwa kualitas buku teks pegangan guru dan buku teks pegangan siswa termasuk pada kategori cukup. Hal ini disebabkan karena terdapat beberapa komponen/subkomponen yang tidak memenuhi standar sebagaimana yang telah ditetapkan oleh BSNP. Buku teks pegangan guru dan buku teks pegangan siswa belum sepe- 
nuhnya memenuhi keseluruhan kriteria baik pada setiap komponen/subkomponen. Kurangnya persiapan penyusun buku teks dalam menyongsong penerapan kurikulum 2013 menjadi faktor utama tidak terpenuhinya kriteri baik pada buku teks. Hal ini dapat dimaklumi karena penerapan kurikulum 2013 yang tergesa-gesa menyebabkan penyusun tidak sepenuhnya memperhatikan standar kualitas yang buku teks.

\section{UCAPAN TERIMA KASIH}

Penulis mengucapkan terima kasih kepada mitra bestari atas kritikan dan masukan yang membangun untuk perbaikan artikel ini.

\section{DAFTAR PUSTAKA}

Amir, M.T. 2009. Inovasi Pendidikan Melalui Problem Based Learning. Jakarta: Prenada Media Group

Bungin, B. 2011. Metodologi Penelitian Kualitatif: Aktualisasi Metodologi ke Arah Varian Kontemporer (Editor). Jakarta: Rajawali Pers.

Cunningsworth, A. 1995. Choosing your Coursebook. Oxford: Heinemann.

Departemen Pendidikan Nasional Republik Indonesia. 2005. Peraturan Menteri Pendidikan Nasional Republik Indonesia Nomor 11 Tahun 2005 Tentang Buku Teks Pelajaran. Jakarta: Departemen Pendidikan Nasional

Departemen Pendidikan Nasional Republik Indonesia. 2008. Peraturan Menteri Pendidikan Nasional Republik Indonesia Nomor 2 Tahun 2008 Tentang Buku Teks Pelajaran. Jakarta: Departemen Pendidikan Nasional.

Fredriksson, C dan Olsson, R. 2006. English Textbook Evaluation: An Investigation into Criteria for Selecting English Textbooks. Sweden: Malmö högskola

Hamalik, O. 2008. Kurikulum dan Pembelajaran. Jakarta: PT Bumi Aksara

Hamalik, O. 2011. Dasar-dasar Pengembangan Kurikulum. Bandung: PT. Remaja Rosdakarya.
Hamdayama, J. 2014. Model dan Metode Pembelajaran Kreatif dan Berkarakter. Jakarta: Ghalia Indonesia

Humphries, S. 2008. Research methodology review The use of textbook analysis, questionnaires and interviews to evaluate EFL textbook implementation. Japan: Kinki University Technical Co

Kementerian Pendidikan dan Kebudayaan RI. 2013. Buku Guru: Bahasa Indonesia Wahana Pengetahuan SMP/MTs Kelas VII. Jakarta: Kementrian Pendidikan dan Kebudayaan.

Kementrian Pendidikan dan Kebudayaan RI. 2013. Peraturan Menteri Pendidikan dan Kebudayaan Nomor 66 Tahun 2013 tentang Standar Penilaian Pendidikan. Jakarta: Kementrian Pendidikan dan Kebudayaan.

Kementerian Pendidikan dan Kebudayaan RI. 2013. Permendikbud Nomor 68 Tahun 2013 tentang Kerangka Dasar dan Struktur Kurikulum SMP-MTs. Jakarta: Kementrian Pendidikan dan Kebudayaan.

Kementerian Pendidikan dan Kebudayaan RI. 2013. Permendikbud nomor 81A tahun 2013 Tentang Implementasi Kurikulum. Jakarta: Kementrian Pendidikan dan Kebudayaan.

Kementerian Pendidikan dan Kebudayaan RI. 2014. Bahasa Indonesia Wahana Pengetahuan SMP/MTS Kelas VII. Jakarta: Kementrian Pendidikan dan Kebudayaan.

Krisnasanjaya dan Muliastuti, L. 1997. Telaah Kurikulum 1994 dan Buku Teks I. Jakarta: Departemen Pendidikan dan Kebudayaan.

Kusaeri. 2014. Acuan dan Teknik Penilaian Proses dan Hasil Belajar dalam Kurikulum 2013. Yogyakarta: Arruzz Media.

Leslie, E. S.1988. Evaluating ELT textbooks. England: Oxford University Press

Loveridge, A.J. 1970. Preparing textbook manuscript: A Guide for author in developing countries. Paris: United Nation Educational and Cultural (UNESCO).

Mahsun. 2014. Teks dalam Pemebelajaran Bahasa Indonesia: Kurikulum 2013. Jakarta: Rajawali Pers.

Moleong, L. J. 2001. Metodologi Penelitian Kualitatif. Bandung: Remaja Rosdakarya.

Muliastuti, L. 2011. Telaah Buku Teks Bahasa Indonesia bagi penutur asing (Jurnal). Jakarta: Fakultas Bahasa dan Seni Universitas Negeri Jakarta

Mulyaningsih, I. 2010. Kualitas Buku 
"Memahami Bahasa Indonesia Untuk SMK Bidang Keahlian Teknik Mesin, Teknik Elektro, dan Teknik Bangunan". Surakarta: Universitas Sebelas Maret (Tesis)

Muslich, M. 2010. Textbook Writing: Dasardasar Pemahaman, Penulisan, dan Pemakaian Buku Teks. Yogyakarta: ArRuzz Media.

Nasution, S. 2006. Kurikulum dan Pembelajaran. Jakarta: PT Bumi Aksara

Pintamtyastirin. 1998. Uji Keterbacaan Bukubuku Teks Bahasa Indonesia SMU Kurikulum 1994. Yogyakarta: IKIP Yogyakarta.

Rahmawati, I.Y. 2014. Kualitas Buku Teks Bahasa Indonesia, Keterbacaan, dan Nilai Pendidikan Karakter (Studi Kasus Buku "Ekspresi Diri dan Akademik" untuk Kelas X Kurikulum 2013). Surakarta: Universitas Sebelas Maret (Tesis)

Sitepu, B.P. 2012. Penulisan Buku Teks Pelajaran. Bandung: PT Remaja Rosdakarya.

Supriadi, D. 2001. Anatomi Buku Sekolah di Indonesia. Yogyakarta: Adicita Karya Nusa.
Suryaman, M. 2007. Dimensi-Dimensi Kontekstual di Dalam Penulisan Buku Teks Pelajaran Bahasa Indonesia. Paper diunduh dari journal.uny.ac.id/index.php/ diksi/article/view/147

Sutopo, H.B. 2006. Metode Penelitian Kualitatif. Surakarta: UNS Press.

Suwandi, S dan Mulyaningsih, I. 2010. 'Buku Pelajaran Bahasa dan Sastra Indonesia untuk Sma Program IPA dan IPS di Kota Surakarta (Sebuah Kajian Kualitas dan Keterbacaan)'. Jurnal AJPBSI hal.1-16.

Syamsul, A dan Adi, K. 2009. Sukses Menulis Buku Ajar dan Rerefensi. Jakarta: PT Grasindo.

Taniredja, T dan Faridli, M. Harmianto, S. 2011. Model-Model Pembelajaran Inovatif dan Efektif. Bandung: Alfabeta

Tarigan, HG dan Tarigan, D. 2009. Telaah Buku Teks Bahasa Indonesia. Bandung: Angkasa.

Tim Penyusun Kamus Bahasa Indonesia. 2008. Kamus Bahasa Indonesia. Jakarta: Pusat Bahasa

Uno, H.B. 2007. Model Pembelajaran: Menciptakan Proses Belajar Mengajar yang Kreatif dan Efektif. Jakarta: PT Bumi Aksara 